\author{
Sharif HOSSAIN, \\ Rajarshi MITRA, \\ Thasinul ABEDIN
}

\title{
AID AND GROWTH IN BANGLADESH: A REASSESSMENT
}

\begin{abstract}
Although the amount of foreign aid received by Bangladesh as a share of GDP has declined over the years, Bangladesh remains one of the heavily aiddependent countries in Asia. The results of most empirical studies that have examined the effectiveness of foreign aid or other forms of development assistance for economic growth have varied considerably depending on the econometric methodology used and the period of study. As the debate and controversy over aid-effectiveness for economic growth continue to grow, this paper reinvestigates the short-run and long-run effects of foreign aid received on percapita real income of Bangladesh over the period 1972-2015. A vector error correction model is estimated. The results indicate lack of any significant short-run and long-run relation between foreign aid and per-capita real income. Results further indicate short-run unidirectional causalities from per-capita real GDP to domestic investment (in proportion to GDP), from government expenditure (in proportion to GDP) to inflation rate, from inflation rate to domestic investment (in
\end{abstract}

(C) Sharif Hossain, Rajarshi Mitra, Thasinul Abedin, 2018.

Hossain Sharif, Md., Professor, Department of Accounting and Information Systems, Faculty of Business Studies, University of Dhaka, Dhaka 1000, Bangladesh.

Mitra Rajarshi, Corresponding Author, Associate Professor, Institute for International Strategy, Tokyo International University, 1-13-1 Matoba-kita, Kawagoe, Saitama 350-1197, Japan.

Abedin Thasinul, Md., Lecturer, Department of Accounting, Faculty of Business Administration, University of Chittagong. 
proportion to GDP), and from domestic investment to foreign aid (as percentages of GDP). Short-run bidirectional causality is observed between per-capita electricity consumption and per-capita real GDP, and between per-capita real GDP and government expenditure (in proportion to GDP).

\section{Key words:}

Cointegration, economic growth, foreign aid, granger causality.

JEL: F35, F43, O53.

\section{Introduction}

Although the developing economies in Asia and Africa, during the last few years, have experienced rapid economic growth due to foreign capital inflow, most of them continue to remain below the poverty line, and consequently, continue to depend on foreign aid for sustainable economic growth and development. Bangladesh has long been one of the heavily aid-dependent countries in Asia. According to the United Nations and the World Bank, the amount of overseas development assistance received by Bangladesh more than doubled from around $\$ 1$ billion in the late 1970 to a staggering $\$ 2.42$ billion in 2014. Although foreign aid received by Bangladesh as a percentage of its GDP declined from $3.62 \%$ in 1972 to $1.12 \%$ in 2015 , a question still arises on the usefulness of foreign aid for economic growth in Bangladesh. Recent studies have argued both for and against the usefulness of foreign aid and other forms of development assistance. Studies that have raised concerns over the effectiveness of foreign aid for economic growth have argued that, the accumulation of foreign aid over time leaves the aid-dependent countries in a debt trap which slows down economic growth in the long-run. The results are mostly inconclusive, varying considerably with the period of study, econometric methodology, and several other factors.

We estimate a vector error correction model and re-investigate the shortrun and long-run effects of foreign aid (in proportion to GDP) on per-capita real GDP of Bangladesh over the period 1972-2015. We also study the short-run and long-run effects of inflation rate, per-capita electricity consumption, domestic investment and government spending (as percentages of GDP) on per-capita real 
GDP. The paper is organized as follows- Section 2 presents a brief literature review; Section 3 presents the data source and descriptive statistics; Section 4 presents the model and the estimation method; Section 5 discusses the main results; Section 6 presents the concluding remarks and policy implications.

\section{Literature Review}

There is lack of general consensus on the effectiveness of aid for economic growth. While Murty et al. (1994), Levy (1998) and Gounder (2001) reported a positive relationship between foreign aid and economic growth, Nyoni (1998), Burke and Ahmadi-Esfahani (2006), Duc (2006) and Mallik (2008) reported a negative or insignificant aid-growth relationship. Pederson (1996) argued that it is not possible to conclude that aid has a positive effect on economic growth. Studies by Mosley (1980), Mosley at al. (1987) and Jensen and Paldam (2003) found no evidence of aid effectiveness for economic growth. Morrisey (2001) found the impact of aid on economic growth is conditional on other variables that are included in the model. Rajan and Subramanian (2008) reported lack of any robust relationship between aid and growth. They found no evidence that aid works better in a good policy environment. Fasanya and Onakoya (2012) observed positive effect of aid on economic growth in Nigeria. Clemens et al. (2012) showed that increases in aid results only in modest increases in economic growth, and economic growth diminishes at substantially high levels of aid.

In case of Bangladesh also, the results of empirical studies on aid-growth relationship are mixed and inconclusive. Islam (1992, 1999) found the effect of aid on economic growth in Bangladesh is positive but insignificant. Quazi (2005) and Hossain (2014) found that aid has positive effect on economic growth in Bangladesh. However, in a recent study, Quibria (2010) observed that aid in Bangladesh has had both positive and negative effects on economic growth. Therefore, due to the mixed results, this paper re-investigates aid effectiveness for economic growth in Bangladesh for the most recent period 1972-2015.

\section{Data Source and Descriptive Statistics}

This study has used annual time series data on Bangladesh from1972 until 2015. The data source is the World Development Indicators of the World Bank group. The dependent variable in the model is per-capita real GDP. The explanatory variables are foreign aid (in proportion to GDP), inflation rate, domestic investment (in proportion to GDP), government expenditure (in proportion to GDP) and per-capita electricity consumption. The variables in the model are indexed 
GDP for per-capita real GDP, FAID for foreign aid (in proportion to GDP),INF for inflation rate, DINV for domestic investment (in proportion to GDP), GOV for government expenditure (in proportion to GDP), and PEC for per-capita electricity consumption. Capital comprises of foreign and domestic capital; therefore, the growth of capital stock depends on foreign aid and domestic investment (as percentages of GDP). The inflation rate is captured by the monetary policy instrument. Per-capita electricity consumption is included since it is an important determinant of economic growth in Bangladesh.

Table1

Descriptive Statistics

\begin{tabular}{|c|c|c|c|c|}
\hline Indicators & Mean & STDEV & CV $(\%)$ & Jarque-Bera \\
\hline GDP & 52.40 & 46.10 & 87.97 & $19.83^{\prime \prime}(0.00)$ \\
\hline DINV & 20.14 & 6.81 & 33.81 & $5.08(0.08)$ \\
\hline FAID & 4.60 & 2.70 & 58.70 & $2.56(0.28)$ \\
\hline PEC & 103.05 & 95.86 & 93.02 & $8.68(0.01)$ \\
\hline GOV & 4.78 & 0.60 & 12.55 & $0.47(0.79)$ \\
\hline INF & 12.07 & 14.94 & 123.78 & $299.45^{\prime \prime}(0.00)$ \\
\hline
\end{tabular}

In Table 1, the variability is highest for inflation rate followed by per-capita electricity consumption, per-capita real GDP, foreign aid (in proportion to GDP), domestic investment (in proportion to GDP) and government expenditure (in proportion to GDP).

Figure 1 shows that foreign aid received by Bangladesh (in proportion to its GDP) declined from $3.62 \%$ in 1972 to 1.12 in 2015 . Over the same period, Figure 2 shows that per-capita real GDP increased from US\$209.58 to US\$ 758.37. In Figure 3, domestic investment (in proportion to GDP) increased from $2.26 \%$ in 1972 to $40.51 \%$ in 2015 . In Figure 4, government expenditure (in proportion to GDP) increased from $4.24 \%$ to $5.57 \%$. In Figure 5 , inflation rate increased from $4.4 \%$ to $6.19 \%$. In Figure 6 , per-capita electricity consumption increased from US\$10.51 to US\$349.47. 


\section{The Model and the Estimation Method}

We examine the aid-growth relationship for Bangladesh by estimating a model of the form

$$
G D P_{t}=A \cdot D I N V_{t}^{\alpha_{1}} \cdot F A I D_{t}^{\alpha_{2}} \cdot P E C_{t}^{\alpha_{3}} \cdot G O V_{t}^{\alpha_{4}} \cdot I N F_{t}^{\alpha_{5}} \cdot e^{\varepsilon_{t}}
$$

The logarithmic transformation of equation (1) is

$$
\ln G D P_{t}=\alpha_{0}+\alpha_{1} \ln D I N V_{t}+\alpha_{2} \ln F A I D_{t}+\alpha_{3} \ln P E C_{t}+\alpha_{4} \ln G O V_{t}+\alpha_{5} \ln I N F_{t}+\varepsilon_{t}
$$

In Table $1,{ }^{* * *} \mathrm{P}<0.01$ denotes significant at $1 \%$ level, ${ }^{* *} \mathrm{P}<0.05$ denotes significant at $5 \%$ level, ${ }^{\star} \mathrm{P}<0.10$ denotes significant at $10 \%$ level. STDEV represents standard deviation.

Here, $\ln A=\alpha_{0}$ and $\alpha_{1}, \alpha_{2}, \alpha_{3}, \alpha_{4}$, and $\alpha_{5}$ measure the sensitivity of percapita real GDP to changes in domestic investment (in proportion to GDP), foreign aid (in proportion to GDP),per-capita electricity consumption, government expenditure (in proportion to GDP) and inflation rate. $\varepsilon_{t}$ represents the random error term. Equation (2)is estimated by the Feasible Modified Ordinary Least Square method (Philips and Hansen, 1990). The appropriate lead and lag length for FMOLS will be selected by the Schwarz Bayesian Information Criterion.

The short-run and long-run relationships are discussed in subsequent sections. Firstly, the Augmented Dickey-Fuller (1979) and Phillips-Perron (1987) unit root tests are performed. The Johansen and Juselius (1990), Engle and Granger (1987) and Phillips-Ouliaris (1990) co-integration tests are next performed followed by the Granger causality test. The short-run and long-run dynamics are next examined. The stability of the short-run parameters are examined by performing the cumulative sum of recursive residuals (CUSUM) and cumulative sum of squares of recursive residuals (CUSUMSQ) tests proposed by Borensztein et al.(1998).

Before estimating equation (2), we first examine if each variable contains a unit root problem. The ADF test is applied. The test is performed for two separate cases: Case 1 that includes both the constant and trend terms and Case 2 that includes the constant term only. Case 1 is described by equation (3) and Case 2 is described by equation (4).

$$
\begin{gathered}
\mathrm{Z}_{\mathrm{t}}=K_{0}+K_{1} t+\delta Z_{t-1}+\sum_{j=1}^{m} \Phi_{j} \Delta Z_{t-j}+u_{t} \\
\mathrm{Z}_{\mathrm{t}}=K_{0}+\delta \mathrm{Z}_{t-1}+\sum_{j=1}^{m} \Phi_{j} \Delta Z_{t-j}+u_{t}
\end{gathered}
$$


In equations (3) and (4), $Z$ is the variable under investigation. The variable is I(1) if $\delta=0$. Appropriate lag length for equations (3) and (4) would be selected by Akaike Information Criterion (AIC) and Schwarz Bayesian Information Criterion (SBIC). The Phillips-Perron test is also performed. The unit root test results are reported in Table2.

Table 2

\section{Unit Root Test Results}

\begin{tabular}{|c|c|c|c|c|}
\hline \multicolumn{5}{|c|}{ Model with constant term [Level Form] } \\
\hline Variables & ADF test & $\mathrm{p}$-value & PP test & p-value \\
\hline $\ln G D P$ & -0.83 & 0.80 & -0.72 & 0.83 \\
\hline $\ln D I N V$ & -1.18 & 0.68 & -6.08 & 0.00 \\
\hline $\ln F A I D$ & 0.07 & 0.96 & -0.47 & 0.89 \\
\hline $\ln P E C$ & -0.80 & 0.81 & -1.02 & 0.74 \\
\hline $\ln G O V$ & -2.59 & 0.10 & -2.92 & 0.05 \\
\hline $\ln I N F$ & -1.52 & 0.51 & -3.78 & 0.01 \\
\hline \multicolumn{5}{|c|}{ Model with constant and trend terms [Level Form] } \\
\hline Variables & ADF test & p-value & PP test & p-value \\
\hline $\ln G D P$ & -4.24 & 0.01 & -4.19 & 0.01 \\
\hline $\ln D I N V$ & -2.36 & 0.39 & -7.62 & 0.00 \\
\hline $\ln F A I D$ & -5.05 & 0.00 & -5.13 & 0.00 \\
\hline $\ln P E C$ & -4.55 & 0.00 & -4.73 & 0.00 \\
\hline $\ln G O V$ & -3.13 & 0.11 & -3.71 & 0.03 \\
\hline $\ln I N F$ & -1.33 & 0.86 & -5.03 & 0.00 \\
\hline \multicolumn{5}{|c|}{ Model with constant term [Difference Form] } \\
\hline Variables & ADF test & p-value & PP test & p-value \\
\hline$\Delta \ln G D P$ & -6.14 & 0.00 & -9.47 & 0.00 \\
\hline$\Delta \ln D I N V$ & -4.12 & 0.00 & -6.73 & 0.00 \\
\hline$\triangle \ln F A I D$ & -10.32 & 0.00 & -11.82 & 0.00 \\
\hline$\triangle \ln P E C$ & -8.06 & 0.00 & -11.27 & 0.00 \\
\hline$\Delta \ln G O V$ & -5.87 & 0.00 & -8.49 & 0.00 \\
\hline$\Delta \ln I N F$ & -3.87 & 0.01 & -17.56 & 0.00 \\
\hline \multirow{2}{*}{\multicolumn{5}{|c|}{\begin{tabular}{|c|c|c|c|}
\multicolumn{3}{c}{ Model with constant and trend terms [Difference Form] } \\
Variables
\end{tabular}}} \\
\hline Variables & ADF test & & PP test & p-value \\
\hline$\Delta \ln G D P$ & -6.05 & 0.00 & -9.28 & 0.00 \\
\hline$\Delta \ln D I N V$ & -6.69 & 0.00 & -6.72 & 0.00 \\
\hline$\Delta \ln F A I D$ & -10.51 & 0.00 & -15.47 & 0.00 \\
\hline$\Delta \ln P E C$ & -7.92 & 0.00 & -12.70 & 0.00 \\
\hline$\Delta \ln G O V$ & -5.79 & 0.00 & -8.37 & 0.00 \\
\hline$\Delta \ln I N F$ & -4.23 & 0.01 & -24.18 & 0.00 \\
\hline
\end{tabular}


The results in Table 2 indicate that all variables are integrated of order one $(\mathrm{I}(1))$.In the second stage, we need to examine if any co-integrating relationship(s)between the variables exist or not. The Johansen and Juselius (1990) cointegration test is performed. The long-run relationship between the variables is described by the following equation

$$
\Delta X_{t}=B_{0}+\Pi X_{t-p}+\sum_{j=1}^{p} B \Delta X_{t-j}+\xi_{t}
$$

In equation (5), $X_{t}$ represents the vector of endogenous I(1) variables; $B_{0}$ represents a vector of constant terms, $B$ is the matrix of coefficients; $\xi_{t}$ is the vector of residuals; $p$ denotes the lag length. All the variables in equation (5) are considered endogenous. The long-run relationship between the variables in $X_{t}$ is determined by the rank of $\Pi$, say, $r$. If $r=0$, the variables in the level form do not have any co-integrating relationship and equation (5) can be transformed into a VAR-model of pth order. If $0<r<\mathrm{n}$, then there are $(n \times r)$ matrices of $\alpha$ and $\beta$ such that $\Pi=\alpha \beta^{\prime}$. The strength of the co-integrating relationship is measured by $\alpha$. $\beta$ represents the co-integrating vector and $\beta^{\prime} X_{t}$ is $\mathrm{I}(0)$ even if $X_{t}$ is $\mathrm{I}(1)$. Johansen and Juselius (1990) co-integration test suggests that there exists cointegrating relationships among the variables in equation (5). Same evidences are obtained from the Engle-Granger two step test (Engle and Granger, 1987) and Phillips-Ouliaris co-integration test (Phillips and Ouliaris, 1990). The results of the co-integration tests are reported in Table 3, Table 4 and Table 5.

Table 3

Johansen and Juselius (1990) Co-integration Test

\begin{tabular}{|c|c|c|}
\hline \multicolumn{2}{|c|}{ Case-1: Intercept (no trend) in CE and VAR } \\
\hline Cointegrating Equation(s) & Trace Statistic & Max-Eigen Statistic \\
\hline & 123.88 & 69.59 \\
None $^{*}$ & {$[95.75]$} & {$[40.08]$} \\
& $(0.00)$ & $0.00)$ \\
\hline & 54.28 & 22.62 \\
At most 1 & {$[69.82]$} & {$[33.88]$} \\
& $(0.45)$ & $0.56)$ \\
\hline & 31.66 & 17.44 \\
At most 2 & {$[47.86]$} & {$[27.58]$} \\
& $(0.63)$ & $0.54)$ \\
\hline & 14.22 & 8.03 \\
At most 3 & {$[29.79]$} & {$[21.13]$} \\
& $(0.83)$ & $0.90)$ \\
\hline
\end{tabular}


Vol. 17. № 4 (67). October-December 2018

ISSN 2519-4070

\begin{tabular}{|c|c|c|}
\hline \hline \multicolumn{3}{|c|}{ Case-2: Intercept and trend in CE and no intercept in VAR } \\
\hline Cointegrating Equation(s) $^{*}$ & Trace Statistic & Max-Eigen Statistic \\
\hline \multirow{2}{*}{ None $^{*}$} & 176.37 & 71.13 \\
& {$[117.71]$} & {$[44.49]$} \\
& $(0.00)$ & $(0.00)$ \\
\hline & 105.25 & 53.11 \\
At most 1 & {$[88.80]$} & {$[38.33]$} \\
& $(0.00)$ & $(0.00)$ \\
\hline \multirow{2}{*}{ At most 2 } & 52.14 & 22.37 \\
& {$[63.88]$} & {$[32.12]$} \\
& $(0.32)$ & $(0.47)$ \\
\hline \multirow{2}{*}{ At most 3 } & 29.77 & 17.41 \\
& {$[42.92]$} & {$[25.82]$} \\
\hline
\end{tabular}

The results in Table 3 indicate one co-integrating equation for Case 1 and two co-integrating equations for Case 2.

In Table 3, the values inside represents the $5 \%$ critical values and the values inside represents the $\mathrm{p}$-values. " $\mathrm{P}<0.01$ denotes significant at $1 \%$ significance level; ${ }^{*} P<0.05$ denotes significant at $5 \%$ significance level;

" $\mathrm{P}<0.10$ denotes significant at $10 \%$ significance level. Appropriate lag length is selected by AIC and SBIC.

Table 4

Engle-Granger (1987) Co-integration Test

\begin{tabular}{|c|c|c|}
\hline Dependent Variables & $\tau$-statistic & Z-statistic \\
\hline \multirow{2}{*}{$\ln G D P$} & $-4.99^{*}$ & -32.07 \\
& $(0.06)$ & $(0.06)$ \\
\hline \multirow{2}{*}{$\ln D I N V$} & -5.91 & -33.01 \\
& $(0.01)$ & $(0.04)$ \\
\hline \multirow{2}{*}{$\ln$. } & -32.85 \\
& -5.09 & $(0.06)$ \\
\hline \multirow{2}{*}{$\ln P E C$} & $(0.05)$ & -23.42 \\
& -3.94 & $(0.31)$ \\
\hline \multirow{2}{*}{$\ln G O V$} & $(0.33)$ & -24.53 \\
& -4.11 & $(0.26)$ \\
\hline \multirow{2}{*}{$\ln I N F$} & $(0.26)$ & -32.56 \\
& -5.35 & $(0.05)$ \\
\hline
\end{tabular}


Table 5

Phillips-Ouliaris (1990) Co-integration Test

\begin{tabular}{|c|c|c|}
\hline Dependent Variables & $\tau$-statistic & Z-statistic \\
\hline \multirow{2}{*}{$\ln G D P$} & -5.03 & -31.51 \\
& $(0.06)$ & $(0.06)$ \\
\hline \multirow{2}{*}{$\ln D I N V$} & -5.99 & -32.21 \\
& $(0.01)$ & $(0.05)$ \\
\hline \multirow{2}{*}{$\ln F A I D$} & -5.21 & -34.71 \\
& $(0.04)$ & $(0.03)$ \\
\hline \multirow{2}{*}{$\ln P E C$} & -4.03 & -24.16 \\
& $(0.29)$ & $(0.27)$ \\
\hline \multirow{2}{*}{$\ln G O V$} & -4.14 & -24.23 \\
& $(0.25)$ & $(0.27)$ \\
\hline \multirow{2}{*}{$\ln I N F$} & -5.62 & -40.71 \\
& $(0.02)$ & $(0.01)$ \\
\hline
\end{tabular}

The results in Table 4 and Table 5 indicate four co-integrating equations. Since the co-integration tests cannot identify causal relationships between the variables, the Engel and Granger (1987) F-test is performed on the firstdifference of all the variables. For long-run causality, an error correction term is included in the VAR system. The augmented form of the Granger causality test in a multivariate VECM framework is given by

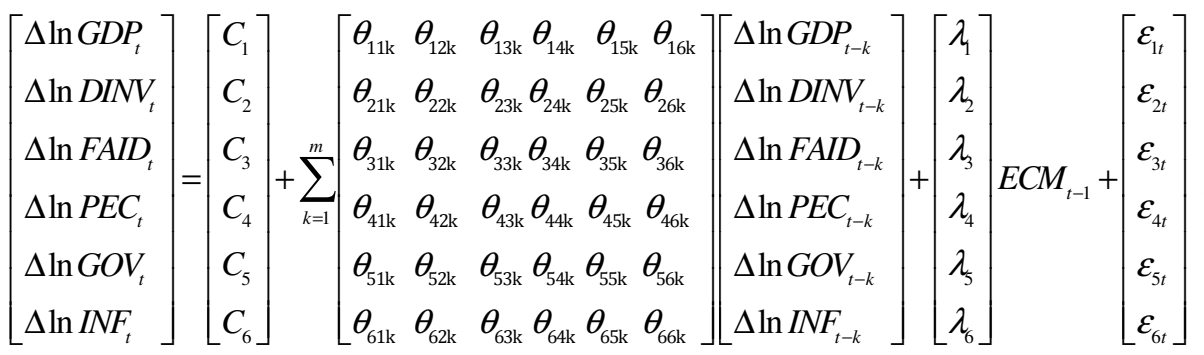

In Table 4 and Table $5,{ }^{* * *} \mathrm{P}<0.01$ denotes significant at $1 \%$ significant level; ${ }^{* *} \mathrm{P}<0.05$ denotes significant at $5 \%$ significance level; $\mathrm{P}<0.10$ denotes significant at $10 \%$ significance level.

The $C^{\prime} s, \theta^{\prime} s, \lambda^{\prime} s$ are the parameters to be estimated. $E C M_{t-1}$ is the one period lagged error terms derived from equation (2). $\varepsilon^{\prime} s$ are serially independent with mean zero and a finite covariance matrix. The appropriate lag length for 
equation (6) is selected by AIC and SBIC. The results of the Granger causality test are reported in Table 6.

Table 6

\section{Granger Causality Test Results}

\begin{tabular}{|c|c|c|c|c|c|c|c|}
\hline & $\Delta \ln G D P$ & $\Delta \ln D I N V$ & $\Delta \ln F A I D$ & $\Delta \ln P E C$ & $\Delta \ln G O V$ & $\Delta \ln I N F$ & $\mathrm{ECM}(-1)$ \\
\hline \multirow{2}{*}{$\Delta \ln G D P$} & & 1.64 & 0.08 & 3.18 & 26.77 & 0.73 & -1.76 \\
& & $(0.21)$ & $(0.78)$ & $(0.08)$ & $(0.00)$ & $(0.39)$ & $(0.09)$ \\
\hline \multirow{2}{*}{$\Delta \ln D I N V$} & 2.77 & & 1.70 & 8.70 & 1.58 & 5.23 & 3.12 \\
& $(0.09)$ & & $(0.20)$ & $(0.01)$ & $(0.22)$ & $(0.03)$ & $(0.00)$ \\
\hline \multirow{2}{*}{$\Delta \ln F A I D$} & 0.26 & 3.79 & & 0.89 & 1.78 & 0.001 & -0.80 \\
& $(0.61)$ & $(0.06)$ & & $(0.35)$ & $(0.19)$ & $(0.98)$ & $(0.43)$ \\
\hline \multirow{2}{*}{$\Delta \ln$ PEC } & 3.39 & 0.20 & 0.87 & & 2.14 & 0.01 & 0.18 \\
& $(0.07)$ & $(0.66)$ & $(0.36)$ & & $(0.15)$ & $(0.91)$ & $(0.86)$ \\
\hline \multirow{2}{*}{$\Delta \ln G O V$} & 3.78 & 1.75 & 0.00 & 1.47 & & 1.58 & 0.02 \\
& $(0.06)$ & $(0.19)$ & $(0.98)$ & $(0.23)$ & & $(0.22)$ & $(0.98)$ \\
\hline \multirow{2}{*}{$\Delta \ln I N F$} & 4.75 & 1.29 & 1.71 & 1.16 & 7.99 & & -0.54 \\
& $(0.04)$ & $(0.26)$ & $(0.19)$ & $(0.29)$ & $(0.01)$ & & $(0.59)$ \\
\hline
\end{tabular}

The results indicate short-run unidirectional causality from per-capita real GDP to domestic investment (in proportion to GDP), from government expenditure (in proportion to GDP) to inflation rate, from inflation rate to domestic investment (in proportion to GDP) and from domestic investment to foreign aid (as percentages of GDP). Short-run bidirectional causality exists between per-capita electricity consumption and per-capita real GDP, and between per-capita real GDP and government expenditure (in proportion to GDP). The significance of ECM(-1) test statistic confirms the existence of long-run causality between the variables.

The estimation of the long-run equation (2) indicates that foreign aid has a negative impact on per-capita real GDP but the coefficient is not statistically significant. The long-run coefficient, although not statistically significant, indicates that for $100 \%$ increase in foreign aid (in proportion to GDP), per-capita real GDP will decrease by $7.85 \%$, ceteris paribus. Government expenditure (in proportion to GDP), has a significantly negative impact on per-capita real GDP. For $100 \%$ increase in government expenditure (in proportion to GDP), per-capita real GDP will decrease by $42.88 \%$, ceteris paribus. Domestic investment (in proportion to GDP), per-capita electricity consumption, and inflation rate have significantly 
positive effects on per-capita real GDP. For $100 \%$ increase in domestic investment (in proportion to GDP), per-capita real GDP will increase by $35.66 \%$, ceteris paribus. For $100 \%$ increase in per-capita electricity consumption, percapita real GDP will increase by $74.88 \%$, ceteris paribus. For $100 \%$ increase in inflation rate, per-capita real GDP will increase by $8.98 \%$, ceteris paribus. The long-run results are reported in Table7.

In Table 6, ${ }^{* * *} \mathrm{P}<0.01$ denotes significant at $1 \%$ significance level; ${ }^{* *} \mathrm{P}<0.05$ denotes significant at $5 \%$ significance level; $\mathrm{P}<0.10$ denotes significant at $10 \%$ significance level. Significance of $E C M_{t-1}$ statistic has ensured the existence of long-run causality between the variables. model

The short-run relation between the variables is described by the following

$$
\begin{aligned}
\Delta \ln G D P_{t} & =\delta_{0}+\sum_{j=0}^{m} \delta_{1 j} \Delta \ln D I N V_{t-j}+\sum_{j=0}^{n} \delta_{2 j} \Delta \ln F A I D_{t-j}+\sum_{j=0}^{p} \delta_{3 j} \Delta \ln P E C_{t-j} \\
& +\sum_{j=0}^{q} \delta_{4 j} \Delta \ln G O V_{t-j}+\sum_{j=0}^{r} \delta_{5 j} \Delta \ln I N F_{t-j}+\lambda E C M_{t-1}+\eta_{t}
\end{aligned}
$$

In equation (7), $\delta_{1}, \delta_{2}, \delta_{3}, \delta_{4}, \delta_{5}$ are the short-run parameters to be estimated. $\lambda$ denotes the speed of adjustment. The optimum lag length is selected by AIC and SBIC. The short-run coefficients are reported in Table 7 .

\section{Table 7}

\section{Long-Run and Short-Run Coefficients}

\begin{tabular}{|c|c|c|}
\hline Variables & Long-run results & Short-run results \\
\hline \multirow{2}{*}{$\ln$ DINV } & 0.36 \\
& $(0.00)$ & \\
\hline \multirow{2}{*}{$\ln F A I D$} & -0.08 \\
& $(0.44)$ \\
\hline \multirow{2}{*}{$\ln P E C$} & 0.75 \\
& $(0.00)$ \\
\hline \multirow{2}{*}{$\ln G O V$} & -0.43 \\
& $(0.08)$ \\
\hline \multirow{2}{*}{$\ln I N F$} & 0.09 \\
& $(0.02)$ \\
\hline Constant & 20.75 \\
& $(0.00)$ \\
\hline
\end{tabular}


Vol. 17. № 4 (67). October-December 2018

ISSN 2519-4070

\begin{tabular}{|c|c|}
\hline Variables & Short-run results \\
\hline $\ln D I N V$ & $\begin{array}{l}0.17 \\
(0.00)\end{array}$ \\
\hline $\ln F A I D$ & $\begin{array}{c}0.03 \\
(0.35) \\
\end{array}$ \\
\hline $\ln P E C$ & $\begin{array}{c}0.16 \\
(0.26)\end{array}$ \\
\hline $\ln G O V$ & $\begin{array}{c}-0.77 \\
(0.00)\end{array}$ \\
\hline $\ln I N F$ & $\begin{array}{l}0.04 \\
(0.03) \\
\end{array}$ \\
\hline $\mathrm{ECM}(-1)$ & $\begin{array}{c}-0.95 \\
(0.00)\end{array}$ \\
\hline Constant & $\begin{array}{l}0.05 \\
(0.05)\end{array}$ \\
\hline JB statistic & $\begin{array}{c}0.08 \\
(0.96)\end{array}$ \\
\hline ARCH statistic & $\begin{array}{c}1.64 \\
(0.21)\end{array}$ \\
\hline
\end{tabular}

In Table-7, ${ }^{*} \mathrm{P}<0.10$ denotes significant at $10 \%$ significance level; ${ }^{*} \mathrm{P}<0.05$ denotes significant at $5 \%$ significance level; ${ }^{* *}{ }^{*} \mathrm{P}<0.01$ denotes significant at $1 \%$ significance level.The short-run equation has been estimated by the CochraineOrcutt iterative method due to auto-correlation problem.

The short-run results indicate that foreign aid has insignificant effect on per-capita real GDP. Domestic investment (in proportion to GDP) and inflation rate have significantly positive effects on per-capita real GDP. Government expenditure (in proportion to GDP) has significantly negative impact on per-capita real GDP. Per-capita electricity consumption has positive impact on per-capita real GDP but it is statistically insignificant. The coefficient of the error correction term $(E C M(-1))$ is negative and significant. If there is any shock to per-capita real GDP due to changes in domestic investment (in proportion to GDP), foreign aid (in proportion to GDP), per-capita electricity consumption, government expenditure (in proportion to GDP), and inflation rate, then per-capita real GDP will be adjusted by $94.45 \%$ in the first year. The entire convergence process will take 1.06 years (less than 1.5 years) to reach into long-run equilibrium.

The short-run parameters are stable as indicated by the CUSUM and CUSUMSQ tests proposed by Borensztein et al.(1998). All values lie within the critical bounds of the estimation period; therefore, the short-run and long-run coefficients can be considered useful for drawing policy implications. The graphs of the CUSUM and CUSUMSQ tests are provided in Figure 7(a) and Figure 7(b), respectively. 
Figure 7(a)

\section{CUSUM Test}

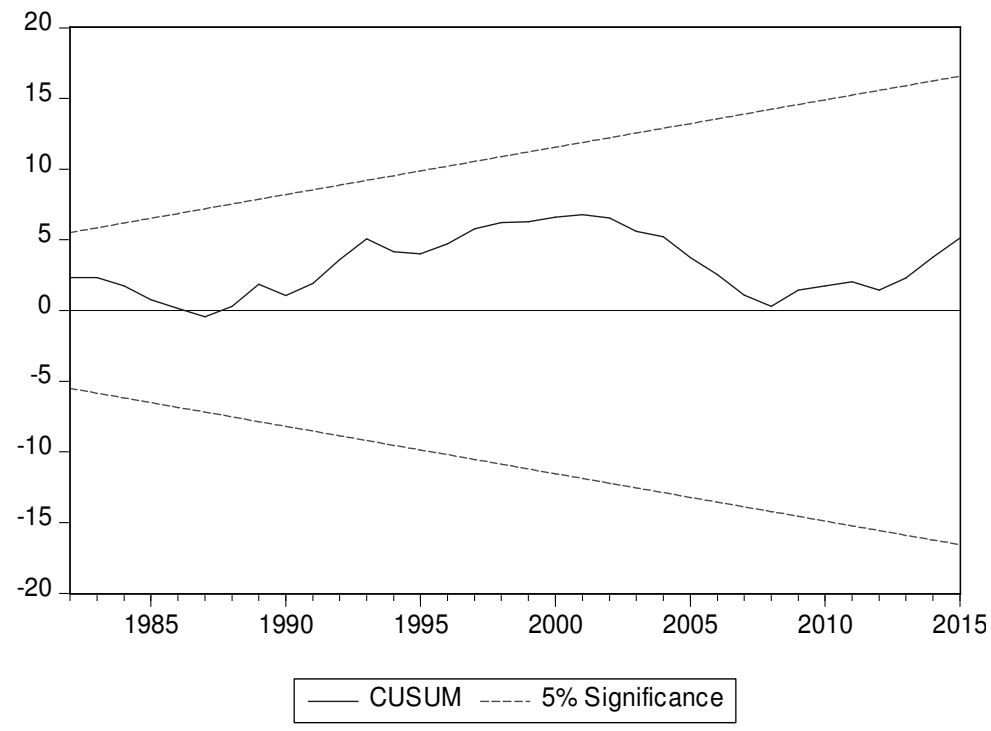

Figure 7(b)

\section{CUSUMSQ Test}

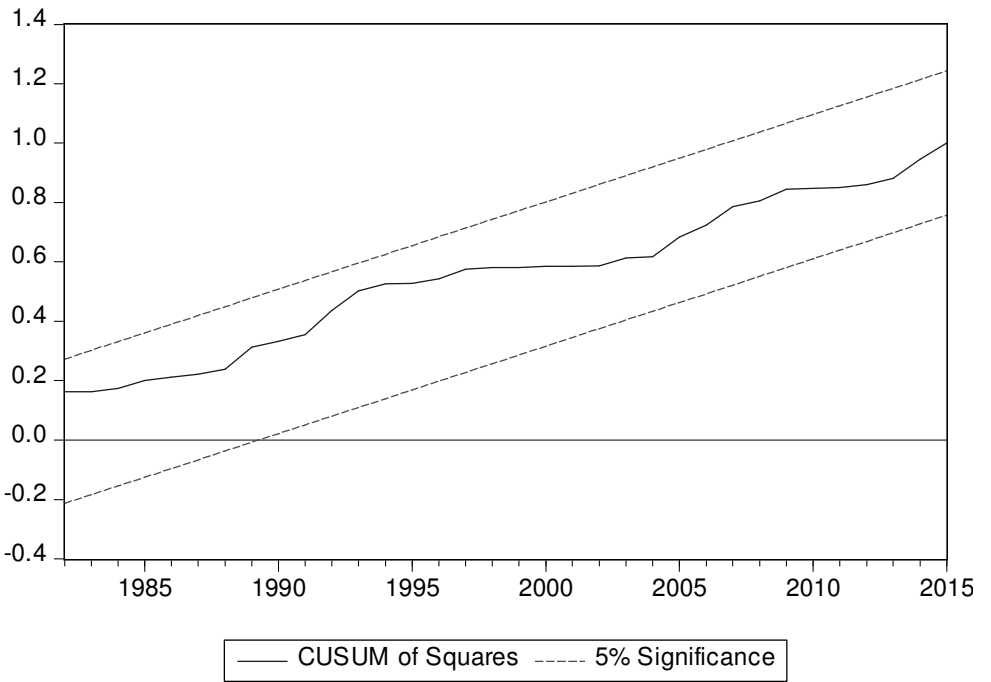




\section{Conclusion}

Although foreign aid received by Bangladesh in proportion to its GDP has declined over the years, Bangladesh continues to be identified as one of the heavily aid-dependent countries in the world. Numerous empirical studies have examined the relation between foreign aid and economic growth in developing economies. There is lack of consensus on the impact of foreign aid on economic growth. In light of the mixed and inconclusive results in existing studies, this paper revisits the literature on aid-growth relationship and reinvestigates the impact of foreign aid on per-capita real income in Bangladesh over the period 19722015.

The results of the dynamic co-integration and causal analysis indicate lack of any significant short-run and long-run relation between foreign aid and percapita real income in Bangladesh. Domestic investment (in proportion to GDP), inflation rate and per-capita electricity consumption are found to have significantly positive effects on per-capita real GDP. Results also indicate short-run unidirectional causal effects from per-capita real GDP to domestic investment (in proportion to GDP), from government expenditure (in proportion to GDP) to inflation rate, from inflation rate to domestic investment (in proportion to GDP), and from domestic investment to foreign aid (as percentages of GDP). Short-run bidirectional causal effects are observed between per-capita electricity consumption and per-capita real GDP, and between per-capita real GDP and government expenditure (in proportion to GDP).

There could be numerous reasons for the insignificant relation between foreign aid and per-capita real income in Bangladesh. According to Boone (1996) and Burnside and Dollar (2000), «bad policy» environment could be considered one reason for the lack of effectiveness of foreign aid for economic growth in developing economies. According to Kosack and Tobin (2006), low human capital can impede economic development. This will happen if foreign aid is used primarily to meet humanitarian needs instead of increasing production capacities in domestic industries. A third possibility could be «loan conditionalities» in which aid-recipients are required to purchase overpriced goods from the donor countries.

Based on the results of this study, we conclude that foreign aid has been ineffective for economic growth in Bangladesh, at least for the sample period under study. Although per-capita real income of Bangladesh increased from 1972 to 2015 , it could possibly have been even higher if not for the ineffectiveness of foreign aid and overseas development assistance. Thus greater emphasis should be placed on the design and implementation of macroeconomic policies aimed at increasing domestic savings and investment in order to reduce the need for foreign aid in Bangladesh in the long-run. 


\section{References}

1. Clemens, C., S. Radelet, R.R. Bhavnani and S. Bazzi (2012). "Counting chickens when they hatch: Timing and the effects of aid on growth» Economic Journal 122, 590-617.

2. Boone, P. (1996). "Politics and the effectiveness of foreign aid» European Economic Review40, 289-329.

3. Borensztein, E., J. De Gregorio and J.-W. Lee, (1998). How does FDI affect economic growth. Journal of International Economics, 45(1): 115-135.

4. Burke, P. J. and F.Z. Ahmadi-Esfahani (2006). "Aid and growth: A study of South East Asia» Journal of Asian Economics 17, 350-362.

5. Burnside, C. and D. Dollar (2000). «Aid, policies and growth» American Economic Review 90, 847-868.

6. Dickey, D. A. \& Fuller W. A. (1979). Distribution of the Estimators for the Autoregressive Time Series with a Unit Root. Journal of the American StatisticalAssociation, 79, 355-367.

7. Duc, V. M. (2006). "Foreign Aid and Economic Growth in the Developing Countries - A Cross-country Empirical Analysis» The Connexions Project, Connexions module: $\mathrm{m} 13519, \quad$ 1-22.Available at: http://cnx.org/content/m13519/latest/

8. Engle, R.F. and C.W.J. Granger (1987). «Cointegration and Error Correction: Representation, Estimation and Testing» Econometrica55, 251-276.

9. Fasanya I. O, Onakoya A B O (2012). -Does Foreign Aid Accelerate Economic Growth? An Empirical Analysis for Nigeriall, Int. J. Econ. Fin. Issues.

10. Gounder, R. (2001). «Aid-growth nexus: empirical evidence from Fiji» Applied Economics 33, 1009-1019.

11. Hosssain, B. (2014). «The Effect of Foreign Aid on the Economic Growth of Bangladesh» Journal of Economics and Development Studies 2, 93-105.

12. Islam, A. (1992). «Foreign Aid and Economic Growth: An Econometric Study of Bangladesh» Journal of Applied Economics24, 541-544.

13. Islam, A. (1999). «Foreign Assistance and Development in Bangladesh» in K.K. Gupta,Eds., Foreign Aid: New Perspectives, Massachusetts: Kluwer.

14. Jensen, P.S. andM. Paldam (2003). "Can the New Aid-Growth Models Be Replicated?" Working Paper No. 2003-17, Institute for Economics: Aarhus.

15. Johansen, S. and K. Juselius (1990). «Maximum Likelihood Estimation and Inference on Cointegration with Applications to the Demand for Money, » Oxford Bulletin of Economics and Statistics52, 169-210. 
16. Kosack, S. and T. Tobin (2006). «Funding Self-Sustaining Development: The Role of Aid, FDI and Government in Economic Success» International Organization 60, 205-243.

17. Levy, V. (1988). «Aid and Growth in Sub-Saharan Africa: The Recent Experience» European Economic Review 32, 1777-1795.

18. Mallik, G. (2008). «Foreign Aid and Economic Growth: A Cointegration Analysis of the Six Poorest African Countries» Economic Analysis and Policy $38,251-260$.

19. Morrisey, O. (2001). «Does Aid Increase Growth in Cameroon»Progress in Development Studies1, 37-50.

20. Mosley, P. (1980). «Aid, savings and growth revisited»Oxford Bulletin of Economics and Statistics42, 79-95.

21. Mosley, P.,J. Hudson, and S. Horrell (1987).»Aid, the Public Sector and the Market in Less Developed Countries»Economic Journa/97, 616-641.

22. Murty, V.N.R., V. Ukpolo, and J.M. Mbaku (1994). «Foreign aid and economic growth in Cameroon: evidence from cointegration tests» Applied Economics Letters1, 161-163.

23. Nyoni, T.S. (1998). «Foreign Aid and Economic Performance in Tanzania» World Development 26, 1235-1240.

24. Pedersen, K.R. (1996). «Aid, Investment and Incentives»Scandinavian Journal of Economics98, $423-438$.

25. Phillips, P. C. B. and Hansen, B. (1990). Statistical Inference in Instrumental Variables Regression with I(1) Processes, The Review of Economic Studies, vol. 57, pp. 99-125.

26. Phillips, P. C. B. and S. Ouliaris (1990). «Asymptotic Properties of Residual Based Tests for Cointegration» Econometrica, Vol. 58, No. 1, pp. 165-193.

27. Phillips P.C.B., and Perron P. (1987). "Testing for a Unit Root in Time Series Regression," Biometrika, Vol. 75, pp. 335-346.

28. Quazi, R. M. (2005). «Effects of Foreign Aid on GDP Growth and Fiscal Behavior: An Econometric Case Study of Bangladesh» The Journal of Developing Areas38, 95-117.

29. Quibria, M.G. (2010). «Aid Effectiveness in Bangladesh: Is the Glass Half Full or Half Empty?» Policy Research Institute of Bangladesh Working Paper, Dhaka, Bangladesh.

30. Rajan, R. and A. Subhramanian (2008). "Aid and Growth: What does the cross-country evidence really show?» The Review of Economic and Statistics $90,643-665$. 
Figure 1

Aid Received in proportion to GDP

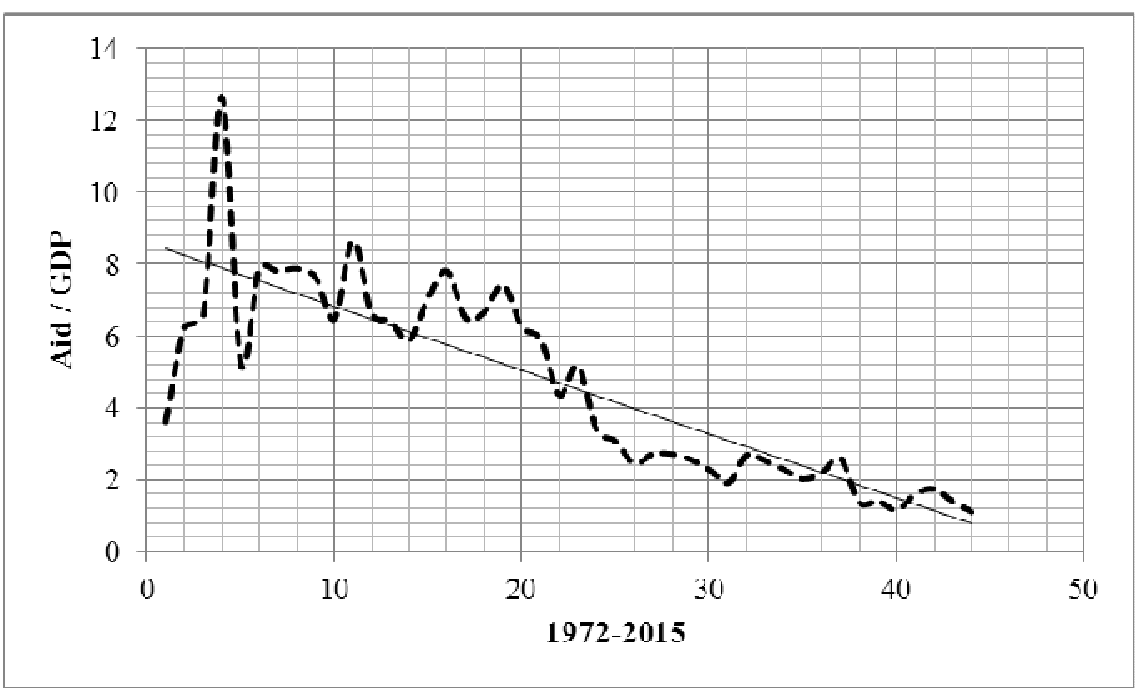

Figure 2

Per-Capita Real GDP of Bangladesh

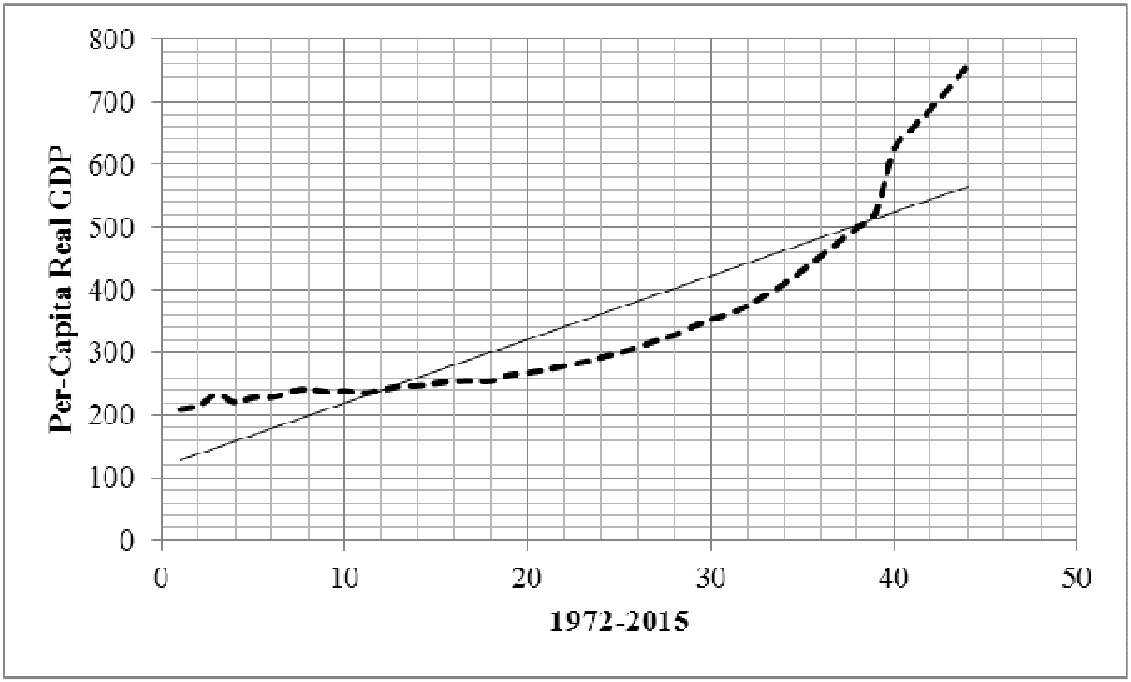




\section{Figure 3}

Domestic Investment in proportion to GDP

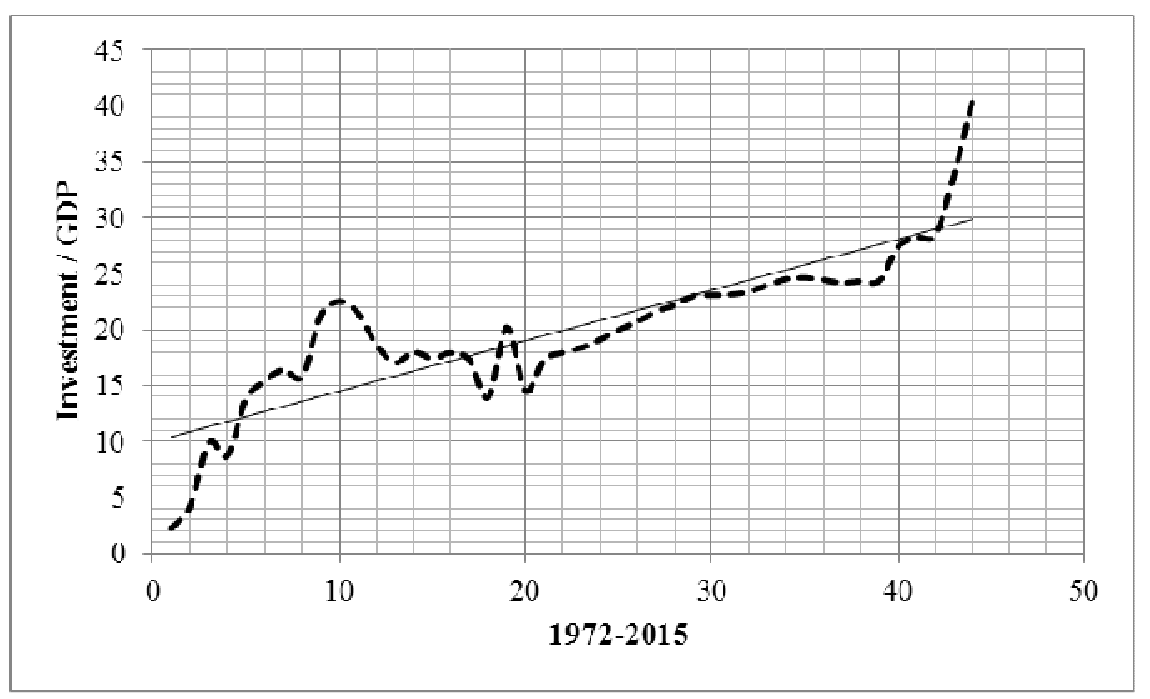

Figure 4

Government Expenditure in proportion to GDP

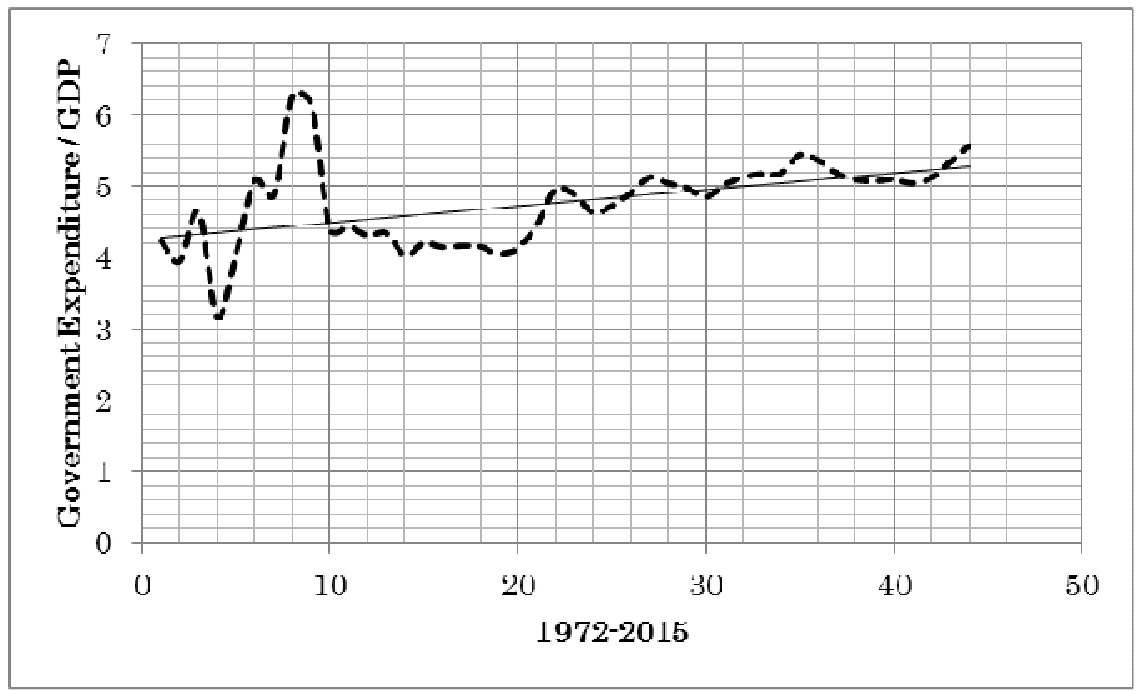


Figure 5

Inflation Rate in Bangladesh

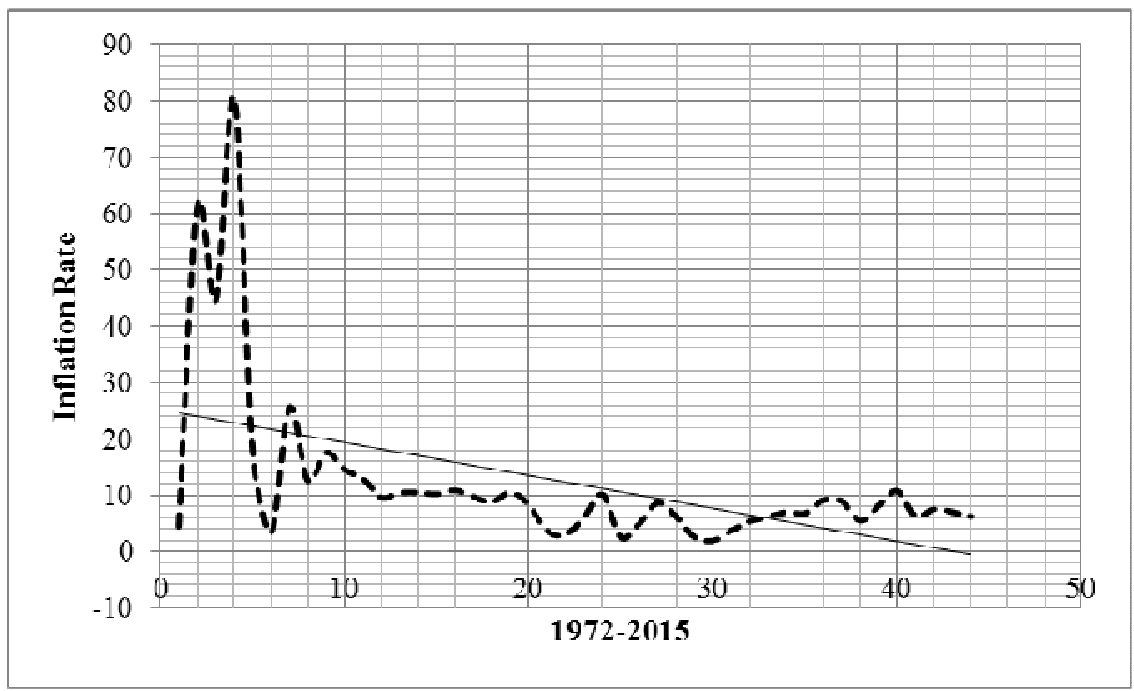

Figure 6

Per-Capita Electricity Consumption in Bangladesh

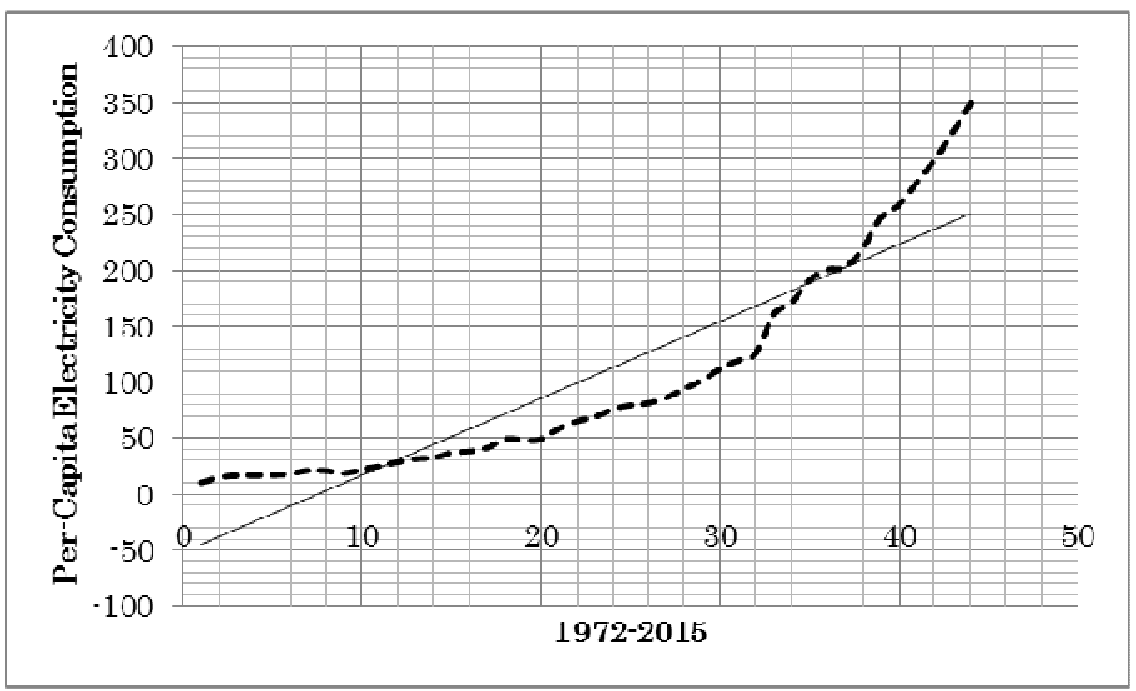

The article was received on 2 November, 2018 